\title{
Penerapan Konsep Atraumatic Care saat Pemasangan Infus dan Venipunktur pada Anak
}

\author{
Ely Mawaddah ${ }^{1}$, Rusmini $^{2}$, Mardiatun $^{3}$, Mira Utami Ningsih ${ }^{4}$ \\ 1,2,3,4 Jurusan Keperawatan Poltekkes Kemenkes Mataram, Indonesia
}

\begin{abstract}
Abstrak
Kondisi morbiditas anak menyebabkan anak membutuhkan tindakan hospitalisasi pada anak. Berbagai prosedur invasive saat perawatan dan pengobatan menimbulkan nyeri berulang yang menyebabkan anak merasa takut akan mengalaminya lagi. Tindakan berulang yang sering menyebabkan nyeri adalah pemasangan infus dan venipuncture sehingga memerlukan prinsip atraumatik selama prosedur dilaksanakan. Studi ini merupakan studi literatur dari pustaka maupun penelitian yang telah dilakukan sebelumnya. Pengumpulan data dilakukan dengan mencari artikel pada beberapa database yaitu Google Scholar, EBSCO, PUBMED dan PROQUEST. Kata kunci yang digunakan diantaranya adalah atraumatic care, children, pediatric, intravenous line, venipuncture. Hasil studi menunjukkan terdapat beberapa cara untuk meminimalkan nyeri pada anak saat dilakukan pemasangan infus dan venipuncture baik secara farmakologi maupun non farmakologi. Tehnik farmakologi dapat menggunakan krim EMLA sebelum dilakukan penusukan, sementara secara non farmakologi dapat menggunakan kompres dingin, distraksi, penggunaan vibrator dan terapi musik. Prinsip atraumatik saat dilakukan tindakan pemasangan infus dan venipuncture perlu diterapkan untuk mencegah trauma pada anak. Perawat dapat memilih intervensi yang digunakan untuk mengurangi nyeri pada anak.
\end{abstract}

Kata Kunci: Anak; Perawatan atraumatik; Pemasangan infus; Intravena; vena puncture

\author{
The Application of the Atraumatic Care Concept during Intravenous Line and Venipuncture \\ Administration in Children; a Literature Review
}

\begin{abstract}
Child morbidity conditions cause children to require hospitalization. Various invasive procedures during treatment and medication cause recurrent pain that causes children to feel afraid of experiencing it again. Repeated actions that often cause pain are the administration of intravenouse line and venipuncture. The principle of atraumatic is strongly required during these procedures. This study is a literature review of previouse study on the application of atraumatice care concept in children. Data was collected by searching for articles in several databases, namely Google Scholar, EBSCO, PUBMED and PROQUEST. The keywords used include atraumatic care; children; pediatric; intravenous line; venipuncture. The results of the study show that there are several ways to minimize pain in children during the administration of intravenous line and venipuncture, both pharmacologically and non-pharmacologically. Pharmacological techniques can be given by applying EMLA cream before stabbing. Non-pharmacologically techniques include $c$ old compresses, distraction, use of vibrators and music therapy. The atraumatic principle when performing infusions and venipuncture needs to be applied to prevent trauma to children. Nurses can choose interventions that are used to reduce pain in children.
\end{abstract}

Keywords: Atraumatic care; Children; Intravenous line; Venipuncture 


\section{PENDAHULUAN}

Anak yang dirawat di rumah sakit memperoleh pengobatan dan perawatan sesuai dengan penyakitnya. Penyakit dan perawatan di rumah sakit sering menjadi krisis yang harus dihadapi anak (Hockenberry dan Wilson, 2011). Krisis ini berkaitan dengan berbagai prosedur invasif, berpisah dari keluarga dan teman, perasaan terisolasi, takut akan sesuatu yang tidak diketahui, hal - hal yang asing di rumah sakit, pengalaman nyeri, terutama pada anak - anak usia sekolah (Brykczyinska dan Simons, 2011). Berbagai prosedur invasif selama dirawat menimbulkan nyeri berulang dan menyebabkan anak merasa takut dan menganggap sebagai suatu hal yang mengancam, anak merasa khawatir dan takut akan mengalaminya lagi (Price dan Gwin, 2008). Salah satu prosedur invasif yang sering dilakukan pada saat anak dirawat di rumah sakit adalah pemasangan infus dan venipunktur (venipuncture).

Tindakan pemasangan infus dan venipunktur sering menimbulkan kondisi nyeri yang akut bagi anak. Nyeri akut merupakan kondisi yang tidak menyenangkan dan pengalaman emosional yang muncul akibat kerusakan yang aktual atau potensial yang tiba-tiba atau lambat dengan berbagai tingkatan baik sedang hingga tinggi dengan diantisipasi atau diprediksi serta waktunya kurang dari 6 bulan (NANDA, 2012). Tindakan venipunktur dan pemasangan infus ini sering dilakukan pada anak yang mengalami dehidrasi, memerlukan pemeriksaan laboratorium, sebelum transfusi darah, pra dan pasca bedah sesuai program pengobatan, pasien yang mendapatkan obat yang harus dimasukkan melalui intravena, serta pasien yang tidak bisa makan dan minum melalui mulut (Asmadi, 2008). Sebagian anak yang mengalami hospitalisasi pernah merasakan penusukan vena sebagai tindakan menyakitkan saat anak dilakukan hospitalisasi (Akdas et al, 2013).

Konsep asuhan keperawatan pada anak meliputi family centered care, case management dan prinsip atraumatic care. Asuhan atraumatik merupakan asuhan teraupetik melalui penggunaan intervensi yang menghapuskan atau memperkecil distres psikologi dan fisik yang diderita oleh anakanak dan keluarga mereka dalam sistem pelayanan kesehatan. Asuhan teraupetik ini mencakup pencegahan, diagnosis, penanganan atau penyembuhan kondisi akut dan kronis (Hockenberry dan Willson, 2011). Tindakan meminimalkan nyeri, stress dan trauma pada anak saat dilakukan pemasangan infus dan venipunktur merupakan bagian dari prinsip atraumatic care.

Fenomena yang terjadi di lapangan, pelaksanaan tindakan pemasangan infus dan venipunktur sering mengabaikan kenyamanan dan keluhan nyeri anak. Saat dilakukan tindakan sering dilakukan berkali-kali penusukan yang justru akan membuat anak lebih trauma dan nyeri. Prinsip atraumatic care pada saat dilakukan venipunktur dan pemasangan infus belum diterapkan dengan baik. Penelitian telah banyak dilakukan untuk mengetahui cara yang efektif untuk meminimalkan nyeri dan efek trauma pada saat dilakukan venapunktur dan pemasangan infus pada anak. Berdasarkan hal tersebut, perlu kiranya dibahas lebih lanjut tentang penerapan prinsip atraumatic care saat dilakukan venapunktur dan pemasangan infus, termasuk hasil penelitian-penelitian yang mendukung. 


\section{METODE}

Penelitian ini merupakan studi literatur yang di ambil dari pustaka maupun penelitian sebelumnya. Pencarian literatur dilakukan terhadap artikel penelitian yang terindex pada Garuda Ristekdikti, Google Scholar, Proquest. Artikel yang dimasukkan dalam review adalah artikel baik yang berbahasa Inggris maupun berbahasa Indonesia dengan desain pre-experimental, studi kasus dan Randomized Controlled Trial. Pencarian di database menggunakan kata kunci: children; atraumatic care; traumatic; infusion; intravenous line; venipuncture; anak, pediatri, perawatan atrauma, infus, vena puncture.

\section{HASIL PENELITIAN}

Hasil pencarian literatur didapatkan 16 artikel dari semua database artikel yang digunakan. Semua artikel tersebut membahas cara menurunkan nyeri dan trauma pada pasien anak yang mendapatkan terapi pemasangan infus atau vena puncture. 16 artikel tersebut terdiri dari 10 studi pre eksperimen, 2 Randomized Controlled Trial, dan 4 studi kasus. Peneliti juga mengidentifikasi bahwa berbagai level usia anak akan mempengaruhi metode yang akan digunakan untuk mengurangi nyeri pada anak, seperti yang dilihat dalam Tabel 1 berikut ini:

Tabel 2.1 Berbagai Penelitian Cara Mengurangi Nyeri Pada Anak Saat Dilakukan Pemasangan Infus Venapuncture

\begin{tabular}{|c|c|c|c|c|c|}
\hline Judul & Desain & Sampel & $\begin{array}{c}\text { Waktu } \\
\text { penelitian }\end{array}$ & $\begin{array}{c}\text { Hasil penelitian } \\
1 \\
\end{array}$ & $\begin{array}{c}\text { Hasil Penelitian } \\
\mathbf{2} \\
\end{array}$ \\
\hline $\begin{array}{l}\text { Cold/Vibration } \\
\text { reduces pain \& } \\
\text { anxiety during } \\
\text { venipuncture }\end{array}$ & $\begin{array}{l}\text { Randomized } \\
\text { Control Trial } \\
\text { (level } 2 \\
\text { evidence) }\end{array}$ & $\begin{array}{l}120 \text { Anak 6- } \\
12 \text { tahun }\end{array}$ & $\begin{array}{l}\text { February- } \\
\text { March } \\
2010\end{array}$ & $\begin{array}{l}\text { Penggunaan } \\
\text { External cold \& } \\
\text { vibration dapat } \\
\text { mengurangi } \\
\text { nyeri dan } \\
\text { kecemasan anak } \\
\text { saat dilakukan } \\
\text { pengambilan } \\
\text { darah }\end{array}$ & $\begin{array}{l}\text { Alat vibrasi } \\
\text { tidak mahal } \\
\text { untuk digunakan }\end{array}$ \\
\hline $\begin{array}{l}\text { Cold/Vibration } \\
\text { on pain \& } \\
\text { anxiety during } \\
\text { venipuncture }\end{array}$ & $\begin{array}{l}\text { Randomized } \\
\text { Control Trial } \\
\text { (level } 2 \\
\text { evidence) }\end{array}$ & $\begin{array}{l}81 \text { Anak 4- } \\
18 \text { Tahun }\end{array}$ & $\begin{array}{l}\text { April- } \\
\text { August } \\
2008\end{array}$ & $\begin{array}{l}\text { Cold \& vibration } \\
\text { dapat } \\
\text { menurunkan } \\
\text { nyeri tanpa } \\
\text { mempengaruhi } \\
\text { keberhasilan } \\
\text { prosedur saat } \\
\text { dilakukan } \\
\text { venapuncture }\end{array}$ & $\begin{array}{l}\text { Alat vibrasi } \\
\text { tidak mahal } \\
\text { untuk digunakan }\end{array}$ \\
\hline $\begin{array}{l}\text { Distracting } \\
\text { children during } \\
\text { blood draws: }\end{array}$ & $\begin{array}{l}\text { Randomized } \\
\text { Control Trial } \\
\text { (level } 2\end{array}$ & $\begin{array}{l}123 \text { Anak 6- } \\
12 \text { Tahun }\end{array}$ & $\begin{array}{l}\text { January } \\
14,2010 \text { to } \\
\text { February }\end{array}$ & $\begin{array}{l}\text { Anak pada } \\
\text { kelompok } \\
\text { experimental }\end{array}$ & $\begin{array}{l}\text { Tingkat } \\
\text { kecemasan } \\
\text { dievaluasi oleh }\end{array}$ \\
\hline
\end{tabular}




\begin{tabular}{|c|c|c|c|c|c|}
\hline $\begin{array}{l}\text { Looking } \\
\text { through } \\
\text { Distraction } \\
\text { Cards }\end{array}$ & evidence) & & 20,2010 & $\begin{array}{l}\text { menunjukkan } \\
\text { penurunan } \\
\text { kecemasan } \\
\text { secara signifikan } \\
\text { dibanding } \\
\text { kelompok } \\
\text { kontrol }\end{array}$ & $\begin{array}{l}\text { orang tua dan } \\
\text { laporan } \\
\text { pengamat secara } \\
\text { signifikan lebih } \\
\text { rendah pada } \\
\text { kelompok } \\
\text { eksperimen }\end{array}$ \\
\hline $\begin{array}{l}\text { EMLA and } \\
\text { amethocaine } \\
\text { for reduction of } \\
\text { children's pain } \\
\text { associated with } \\
\text { needle } \\
\text { insertion }\end{array}$ & $\begin{array}{l}\text { Systematic } \\
\text { review of } \\
\text { randomized } \\
\text { control trials } \\
\text { (Level } 1 \\
\text { evidence) }\end{array}$ & $\begin{array}{l}534 \text { Anak } 3 \\
\text { bulan - } 15 \\
\text { tahun }\end{array}$ & Varied & $\begin{array}{l}\text { Amethocaine } \\
\text { secara signifikan } \\
\text { lebih disukai } \\
\text { dibanding } \\
\text { EMLA } \\
\text { Hasil observasi: } \\
\text { Perbedaan itu } \\
\text { tidak signifikan }\end{array}$ & $\begin{array}{l}\text { Perbandingan } \\
\text { reaksi negatif } \\
\text { menunjukkan } \\
\text { EMLA } \\
\text { mengakibatkan } \\
\text { kemerahan lebih } \\
\text { sering daripada } \\
\text { amethocaine }\end{array}$ \\
\hline $\begin{array}{l}\text { Comparison } \\
\text { study of Jet- } \\
\text { delivered } \\
\text { lidocaine, jet- } \\
\text { delivered } \\
\text { placebo and no } \\
\text { pretreatment } \\
\text { for pain relief } \\
\text { during needle } \\
\text { insertion }\end{array}$ & $\begin{array}{l}\text { Randomized } \\
\text { control trail } \\
\text { (level } 2 \\
\text { evidence) }\end{array}$ & $\begin{array}{l}197 \text { children } \\
\text { 5-18 tahun }\end{array}$ & $\begin{array}{l}\text { April 1, } \\
2007 \text { to } \\
\text { August } 1, \\
2008\end{array}$ & $\begin{array}{l}\text { Tidak ada } \\
\text { perbedaan } \\
\text { signifikan antara } \\
\text { lidokain dan } \\
\text { plasebo untuk } \\
\text { mengurangi rasa } \\
\text { sakit pada insersi } \\
\text { jarum }\end{array}$ & $\begin{array}{l}\text { Kelompok } \\
\text { intervensi } \\
\text { menunjukkan } \\
\text { nyeri yang lebih } \\
\text { tinggi } \\
\text { dibandingkan } \\
\text { kelompok } \\
\text { kontrol }\end{array}$ \\
\hline $\begin{array}{l}\text { Comparison of } \\
\text { pain reduction } \\
\text { during needle } \\
\text { insertion using } \\
\text { topical } \\
\text { xylocaine spray } \\
\text { to no } \\
\text { intervention }\end{array}$ & $\begin{array}{l}\text { Randomized } \\
\text { control trail } \\
\text { (level } 2 \\
\text { evidence) }\end{array}$ & $\begin{array}{l}40 \text { neonatus } \\
\text { dibawah } 34 \\
\text { minggu } \\
\text { gestasi }\end{array}$ & $\begin{array}{l}\text { July- } \\
\text { November } \\
2004\end{array}$ & $\begin{array}{l}\text { Kelompok } \\
\text { intervensi } \\
\text { menunjukkan } \\
\text { kondisi yang } \\
\text { lebih stabil pada } \\
\text { denyut jantung, } \\
\text { tingkat } \\
\text { pernapasan ,dan } \\
\text { saturasi oksigen } \\
\text { selama insersi } \\
\text { jarum }\end{array}$ & $\begin{array}{l}\text { Xylocaine } \\
\text { semprot dapat } \\
\text { bertindak cepat } \\
\text { dan biaya } \\
\text { metode yang } \\
\text { efektif untuk } \\
\text { mengurangi rasa } \\
\text { sakit }\end{array}$ \\
\hline $\begin{array}{l}\text { Evaluating } \\
\text { reduction in } \\
\text { pain of } \\
\text { newborns } \\
\text { receiving } \\
\text { glucose } \\
\text { compared to } \\
\text { EMLA cream } \\
\text { prior to } \\
\text { venipuncture }\end{array}$ & $\begin{array}{l}\text { Randomized } \\
\text { controlled } \\
\text { trial, double } \\
\text { blind }\end{array}$ & $\begin{array}{l}201 \text { bayi } \\
\text { yang baru } \\
\text { lahir } \\
\text { menjalani } \\
\text { venipuncture } \\
\text { untuk tujuan } \\
\text { klinis }\end{array}$ & $\begin{array}{l}\text { January } \\
1999- \\
\text { October } \\
2000\end{array}$ & $\begin{array}{l}\text { Glukosa efektif } \\
\text { dalam } \\
\text { mengurangi } \\
\text { gejala sakit dari } \\
\text { venipuncture } \\
\text { pada bayi baru } \\
\text { lahir }\end{array}$ & $\begin{array}{l}\text { Glucose lebih } \\
\text { efektif } \\
\text { dibandingkan } \\
\text { EMLA cream }\end{array}$ \\
\hline $\begin{array}{l}\text { Comparing non } \\
\text { nutritive } \\
\text { sucking to } \\
\text { glucose }\end{array}$ & $\begin{array}{l}\text { Randomized } \\
\text { controlled } \\
\text { trial, parallel } \\
\text { group }\end{array}$ & $\begin{array}{l}105 \\
\text { neonattus } \\
\text { setidaknya } \\
32 \text { minggu }\end{array}$ & $\begin{array}{l}\text { June- } \\
\text { October } \\
2006\end{array}$ & $\begin{array}{l}\text { NNS efektif } \\
\text { dapat mengu- } \\
\text { rangi rasa sakit } \\
\text { saat }\end{array}$ & $\begin{array}{l}\text { GW efektif } \\
\text { dapat } \\
\text { mengurangi rasa } \\
\text { sakit saat }\end{array}$ \\
\hline
\end{tabular}




\begin{tabular}{|c|c|c|c|c|c|}
\hline $\begin{array}{l}\text { solution for } \\
\text { reduction in } \\
\text { pain during } \\
\text { venipuncture }\end{array}$ & & kehamilan & & venipunctures & venipunctures \\
\hline $\begin{array}{l}\text { Evaluation of } \\
\text { studies looking } \\
\text { at pain } \\
\text { reduction of } \\
\text { needle related } \\
\text { procedures } \\
\text { with sweet } \\
\text { tasting } \\
\text { solutions }\end{array}$ & $\begin{array}{l}\text { Systematic } \\
\text { review of } \\
\text { randomized } \\
\text { controlled } \\
\text { trials }\end{array}$ & $\begin{array}{l}4 \text { studi , } 330 \\
\text { anak-anak } \\
12 \text { bulan } \\
\text { sampai } 16 \\
\text { tahun }\end{array}$ & Varied & $\begin{array}{l}\text { Bayi } 0-12 \text { bulan } \\
\text { mengalami } \\
\text { penurunan rasa } \\
\text { sakit dengan } \\
\text { solusi mencicipi } \\
\text { manis }\end{array}$ & $\begin{array}{l}\text { Anak-anak 1-16 } \\
\text { tahun tidak } \\
\text { mengalami } \\
\text { penurunan rasa } \\
\text { sakit dengan } \\
\text { solusi mencicipi } \\
\text { manis }\end{array}$ \\
\hline
\end{tabular}

Sumber: Presentasi Riset Crow, Reishus, McMillan, Corkery, Chesser

\section{PEMBAHASAN}

Perawatan atraumatik menjadi salah satu perspektif dalam keperawatan anak. Beberapa ahli mendefinisikan perawatan Atraumatik sebagai pemberian perawatan dengan cara meminimalkan ancaman emosi dan fisik pada anak (Bowden \& Greeberg, 2010). Definisi lain, perawatan atraumatik adalah perawatan terapeutik pada tatanan pelayanan kesehatan, oleh personel, dan melalui penggunaan intervensi yang meminimalisasi/ mengeliminasi pengalaman distress psikologis dan fisik pada anak dan keluarganya pada sistem pelayanan kesehatan (Hockenberry dan Willson, 2011). Perawatan atraumatik ini diberikan oleh tenaga kesehatan dalam tatanan kesehatan anak, melalui tindakan yang diusahakan mengurangi stress fisik maupun stress psikologis yang dialami anak maupun orang tuanya.

Pada umumnya anak yang dirawat di rumah sakit takut kepada petugas kesehatan yang memakai pakaian serba putih, selain itu mereka beranggapan mereka adalah orang baru, hal ini juga dikarenakan anak-anak memiliki persepsi tersendiri terhadap petugas kesehatan yang memakai pakaian serba putih, mereka beranggapan bahwa petugas kesehatan di rumah sakit hendak menyakiti mereka. Tindakan prosedur invasif yang berulang-ulang tak jarang meninggalkan rasa nyeri dan trauma pada anak, selain itu perubahan lingkungan antara rumah sakit dan rumah dapat menimbulkan trauma pada anak. Untuk mengatasi masalah tersebut, maka perawat harus menerapkan perawatan atraumatik.

Hockenberry \& Wilson (2011) menyebutkan prinsip perawatan atraumatik yaitu mencegah atau meminimalkan perpisahan anak dari orangtua, meningkatkan kontrol diri anak selama perawatan, mencegah atau meminimalkan cedera tubuh/rasa nyeri. Sementara menurut Beevi (2009), ada tiga cara untuk memberikan perawatan atraumatik: a). menjaga dan menghindari anak berpisah dari keluarganya, b). menyediakan kenyamanan untuk anak, c). meminimalkan injury dan nyeri. Meminimalkan injury dan nyeri meliputi berbagai prosedur yang menyakitkan seperti suntikan, kegelisahan, ketidakberdayaan, tidur yang tidak nyaman, pengekangan, suara bising, bau yang tidak sedap dan lain-lain (Kyle, 2008). 
Pemasangan infus dan venapunktur merupakan salah satu tindakan yang paling sering dilakukan saat anak dilakukan hospitaslisasi dan menjadi salah satu tindakan yang menyakitkan (Akdas, et al, 2013). Penelitian-penelitian yang melibatkan tenaga kesehatan lintas profesi telah dilakukan untuk mencari cara yang efektif mengurangi efek trauma dan nyeri saat anak dilakukan pemasangan infus dan venipunktur. Cara-cara tersebut dapat penulis golongkan menjadi 2 yaitu:

\section{Tekhnik Farmakologi}

Mengurangi nyeri pada saat dilakukan pemasangan infus dan venapunktur dengan farmakologi dapat dilakukan dengan berbagai cara, diantaranya penggunaan EMLA cream sebelum dilakukan pemasangan infus. Penelitian yang mendukung adalah Penelitian yang dilakukan oleh $\mathrm{Na}$ Ahn et al (2013) tentang penggunaan EMLA cream untuk mengurangi nyeri pada anak preschool, penelitian ini menggunakan desain pre- and post- test-designed study dengan non-equivalent control group. Anak yang berusia 36-72 bulan dibagi menjadi 23 orang sebagai kelompok intervensi dan 26 orang sebagai kelompok control. Hasil penelitian menunjukkan penggunaan EMLA Cream sangat berpengaruh secara signifikan dalam menurunkan nyeri anak saat dilakukan pemasangan infus tetapi level $\mathrm{SpO} 2$ tidak berbeda secara signifikan.

EMLA Cream dapat digunakan 5 menit sebelum dilakukan IV insertion, cream ini mengandung per gram $25 \mathrm{mg}$ lidocaine dan $25 \mathrm{mg}$ prilocaine (Britt, 2005). EMLA cream dalam berbagai penelitian telah terbukti dapat menurunkan nyeri pada anak saat dilakukan penusukan jarum, namun demikian prosedur ini juga memiliki kelebihan dan kekurangan, seperti yang diungkapkan oleh Grosso dan Breeden (2006), kekurangan penggunaan EMLA cream adalah 1). Memerlukan instruksi dokter sebelum digunakan, 2). Dibutuhkan waktu untuk menunggu reaksi EMLA cream, 3). Adanya warna putih setelah dioleskan menyebabkan kesulitan untuk melihat vena, 4). Adanya kemungkinan bahwa EMLA cream dapat menyebabkan vasokonstriksi dari vena yang tersedia. Sementara itu kelebihan penggunaan EMLA cream adalah telah adanya bukti bahwa penggunaannya dapat menurunkan nyeri sehingga mempermudah dalam pemasangan infus dan meminimalkan stressor dan efek trauma pada anak. Alternatif lain selain EMLA Cream dapat menggunakan L.M.X.4 yang mengandung 4\% liposomal lidocaine (Britt, 2005).

Melihat dan mencari vena pada bayi dan anak kecil lebih sulit dibandingkan pada orang dewasa, anak kecil dan bayi memiliki pembuluh darah perifer yang lebih kecil, anak dan bayi memiliki lebih banyak lemak subkutan, serta rentan terhadap vasokonstriksi. Selain itu bayi dan anak sulit untuk tetap diam dan kooperatif selama prosedur yang menyakitkan daripada orang dewasa. Karena itu, cara lain untuk memudahkan melihat dan mengakses vena, dan menghindari terjadinya penusukan berulangulang yang dapat menyebabkan trauma pada anak adalah dengan menggunakan vein viewing system, hal ini sesuai dengan dengan hasil penelitian yang dilakukan oleh Chapman et al (2011) tentang penggunaan veinviewer pada anak saat dilakukan pemasangan infus di unit gawat darurat. Peneliti menggunakan sampel acak dari anak-anak yang berusia 0-17 tahun yang akan dipasang infus tetapi 
tidak darurat. Sampel sebanyak 323 pasien dibagi menjadi dua kelompok yaitu kelompok yang dipasang infus dengan prosedur standar dan kelompok yang dipasang infus dengan dengan vein viewer. Hasil yang diperoleh usia, jenis kelamin, dan indeks massa tubuh (BMI) tidak berbeda antar kelompok, tidak ada perbedaan waktu pemasangan infus, jumlah usaha pemasangan infus, atau skor nyeri untuk kelompok studi secara keseluruhan. Namun, kelompok anak-anak usia 0 sampai tahun $(\mathrm{n}=$ 107) menunjukkan bahwa Vein Viewer dapat menurunkan waktu untuk pemasangan Infus.

\section{Tekhnik Non Farmakologi}

Tindakan untuk untuk menurunkan nyeri dan stressor pada anak saat dilakukan pemasangan infus dan venipunktur tidak hanya dilakukan dengan menggunakan obat namun juga non farmakologi. Penelitian telah dilakukan untuk membuktikan keefektifan tekhnik non farmakologi saat pemasangan infus dan venipunktur untuk mengatasi nyeri dan stressor pada anak. Penelitian yang dilakukan oleh Mariyam dan Widodo (2012) bertujuan mengidentifikasi pengaruh guided imagery terhadap tingkat nyeri anak saat pemasangan infus. Jenis penelitian quasi eksperiment dengan sampel 28 intervensi dan 28 kontrol di RSUD Kota Semarang. Hasil penelitian menunjukkan ada perbedaan rata-rata tingkat nyeri anak pada kelompok intervensi dan kontrol. Guided Imagery dapat digunakan untuk mengurangi tingkat nyeri anak usia sekolah saat pemasangan infus.

Penelitian lain dilakukan oleh Latta dan Buoy (2012) yang menggunakan vibrator "Buzzy Bee" dan dikombinasikan dengan kompres dingin untuk menurunkan nyeri saat dilakukan pemasangan infus dan pengambilan specimen darah. Jumlah sampel yang digunakan sebanyak 47 anak di pediatric unit di Hinsdale Hospital, hasil penelitian menunjukkan secara statistic tidak ada penurunan nyeri namun perlu dilakukan penelitian ulang dengan menggunakan kelompok control. Penelitian lain yang menggunakan kompres dingin dan es batu telah dilakukan oleh Fauzi dan Hendayani (2013) dan Sulistyani (2009). Penelitian tersebut menyimpulkan kompres dingin efektif menurunkan nyeri pada anak saat dilakukan pemasangan infus.

Pemasangan infus dengan prinsip atraumatic care juga dapat dilakukan dengan menjaga dan menghindari anak berpisah dari keluarganya untuk memberikan kenyamanan (Beevi, 2009). Hal ini juga sesuai dengan konsep perawatan anak yang berpusat pada keluarga (family centered care). Penelitian tentang pelibatan keluarga saat dilakukan pemasangan infus juga telah banyak dilakukan, salah satu diantaranya adalah penelitian yang telah dilakukan oleh Sparks, Setlik dan Luhman (2007) tentang pengaturan posisi dan pegangan orang tua saat dilakukan pemasangan infuse. Penelitian ini dilakukan pada anak yang berumur 9 bulan sampai 4 tahun $(\mathrm{N}=118)$. Distress scores dinilai dengan Behavior Rating Scale dan signifikan bermakna pada upright positioning group $(\mathrm{p}=.000)$; orang tua merasa puas dengan upright position karena dapat menurunkan stressor pada anak. Penelitian yang melibatkan orang tua juga dilakukan oleh Lestari (2013) tentang Dampak Dekapan Keluarga dan Pemberian Posisi Duduk terhadap Disstres Anak Saat dilakukan Pemasangan Infus. Penelitian ini melibatkan sampel sebanyak 30 anak pra sekolah dengan metode quasi eksperimental, hasil penelitian 
menunjukkan ada pengaruh signifikan pada anak yang diberi dekapan dibandingkan dengan anak yang tidak di dekap, dengan score stress yang lebih rendah pada anak yang diberi dekapan.

Penelitian-penelitian yang telah dilakukan merupakan usaha profesional tenaga kesehatan untuk mengurangi dampak yang merugikan dari hospitalisasi bagi anak-anak dan keluarga. Strategi lainnya dapat dilakukan dengan: kebijakan perawatan yang berpusat pada keluarga, dekorasi ruang yang ramah bagi anak dan lingkungan, mebel dan peralatan yang sesuai untuk anak dan penyediaan ruang bermain. Tindakan mandiri keperawatan lainnya dalam mengurangi nyeri saat pemasangan infus dan venipunktur pada anak yang usianya lebih besar dapat berupa tindakan distraksi seperti bermain therapeutic dan mendengarkan musik, Peneliti di Kanada mengungkapkan bahwa musik ternyata bisa mengurangi stres pada anak saat disuntik dengan jarum infus. Penelitian yang dipublikasikan dalam jurnal medis JAMA Pediatrics ini memperkuat studi sebelumnya bahwa musik secara signifikan mengurangi rasa sakit dan cemas selama prosedur medis.

Prosedur medis dan keperawatan menjadi stressor tersendiri bagi anak- anak yang dilakukan perawatan, karena itu perlu usaha maksimal dan penelitian yang berkelanjutan untuk mencari cara yang efektif dalam menurunkan stressor tersebut baik fisik maupun psikologis. Kedepannya perlu dipikirkan untuk mengkombinasikan tekhnik farmakologi dan non farmakologi sebagai upaya maksimal mengurangi dampak hospitalisasi pada anak. Salah satu usaha untuk menemukan cara yang efektif mengurangi nyeri pada anak saat dilakukan penusukan vena dilakukan oleh Crow, Reishus, McMillan, Corkery, Chesser dari Universitas Alaska, para peneliti melakukan systematic review dengan pertanyaan "What are the best nursing practices to reduce the pain of venipuncture in children?", Peneliti memamfaatkan data base CINAHL, Cochrane, Google Scholar, PsychINFO. Peneliti menyimpulkan mengurangi nyeri saat dilakukan penusukan vena akan dapat: 1). mengurangi kecemasan dan melindungi dari peningkatan nyeri pada tindakan berikutnya, 2). metode mengontrol nyeri dapat dilakukan dengan berbagai metode termasuk yang non invasive, 3). diperlukan pelatihan yang berkelanjutan bagi Perawat untuk mengurangi nyeri pada anak.

Merujuk pada Tabel 1. dapat kita lihat bahwa pada bayi dibawah 1 tahun, memberikan cairan manis dapat mengurangi nyeri (Gradin et al., 2002; Harrison et al., 2011), sementara untuk anak usia lebih besar 6-12 tahun, teknik distraksi terbukti dapat digunakan untuk menurunkan nyeri (Inal \& Kelleci, 2011), selain itu dapat pula menggunakan External cold and vibration (Baxter et al., 2011; Inal \& Kelleci, 2012). Reaksi anak terhadap nyeri berbeda sesuai dengan usia perkembangannya. Kemampuan anak untuk menggambarkan jenis dan intensitas nyeri mulai berkembang pada usia pra sekolah (4-6 tahun), meskipun pada usia toddler anak sudah mampu menunjuk lokasi nyeri (Hockenberry\&Willson, 2011). Konsekuensinya perbedaan usia dan tahap perkembangan anak akan mempengaruhi metode yang digunakan untuk mengurangi nyeri saat dilakukan pemasangan infus dan venapunktur. 


\section{KESIMPULAN}

Perawatan atraumatik yaitu bentuk perawatan terapeutik yang diberikan oleh tenaga kesehatan dalam tatanan kesehatan anak, melalui tindakan mengurangi nyeri, stress fisik maupun stress psikologis yang dialami anak maupun orang tua. Tindakan untuk mengurangi nyeri, stress fisik maupun psikologis pada saat dilakukan pemasangan infus dan venapunktur pada anak yang mengalami hospitalisasi dapat dilakukan dengan tekhnik farmakologi dan non farmakologi. Tekhnik farmakologi dapat melalui pemberian EMLA cream dan penggunaan veinviewer, sedangkan non farmakologi dapat dilakukan dengan pemberian kompres dingin, distraksi, mendengarkan musik, therapeutic play, quided imagery dan pelibatan orang tua melalui dekapan dan pengaturan posisi, memberikan cairan yang manis (glukosa) dan vibrator. Berbagai level usia anak akan mempengaruhi cara dalam menurunkan nyeri dan kecemasan saat dilakukan venapuncture dan pemasangan infuse, pada bayi tindakan mengurangi nyeri dapat dilakukan dengan mencicipi cairan yang manis sementara pada anak yang lebih besar dapat menggunakan tekhnik distraksi dan penggunaan analgetik topikal.

\section{DAFTAR PUSTAKA}

Akdas $\mathrm{O}$, et al. (2013). 'The effects of Valsalva maneuver on venipuncture pain in children: comparison to EMLA(®) (lidocaine-prilocaine cream). Diunduh tanggal 19 Nopember 2014. http://www.ncbi.nlm.nih.gov/pubmed/24243080.

Asmadi. (2008). Teknik Prosedural Keperawatan : Konsep Dan Aplikasi Kebutuhan Dasar Klien. Jakarta: Salemba Medika

Auerbach, M., Tunik, M., \& Mojica, M. (2009). A Randomized, Double-Blind Controlled Study Of Jet Lidocaine Compared To Jet Placebo For Pain Relief In Children Undergoing Needle Insertion In The Emergency Department. Diunduh tanggal 18 November 2014. http://onlinelibrary.wiley.com/doi/10.1111/2009/abstract.

Baxter, A., Cohen, L., McElvery, H., Lawson, M., \& von Baeyer, C. (2011). An Integration Of Vibration And Cold Relieves Venipuncture Pain In A Pediatric Emergency Department. Pediatric $\begin{array}{lll}\text { Emergency Care Journal, 27(12). } & \text {. }\end{array}$ http://science.kennesaw.edu/ mlawso16/Baxter\%201st\%20Buzzy\%20Paper.pdf.

Beevi, A. T. M.(2009). Textbook of pediatric nursing. Mosby: Elsevier

Bowden, VR. \& Greeberg, CS. (2011). Pediatric Nursing Procedure. Philadelphia Lippincott Williams

Britt, R.B. (2005). Using EMLA Cream Before Venipuncture. Retrivied from http://journals.lww.com/nursing/Citation/2005/01000/Using_EMLA_cream_before_venipuncture. 12.aspx

Brykczynska, G. M. Simons, J. (2011). Ethical Philosophical Aspect Of Nursing Children And Young People. West Sussex: Blackwell Publishing 
Chapman, et al (2011). Vein viewer-Assisted Intravenous Catheter Placement In A Pediatric Emergency Department. Academic emergency medicine journal, 18:966-971.

Fauzi\&Hendayani (2013). Pengaruh Kompres Dingin Terhadap Tingkat Nyeri Pada Prosedur Invasive Pemasangan Infus Anak Usia Sekolah Di RSUD Bendan. Skripsi (tidak di publikasikan)

Hockenberry, M. J \& Wilson, D. (2011). Wong's nursing care of infants and children. 9th ed. St Louis : Mosby Elsevier

Inal, S., \& Kelleci, M. (2012). Distracting children during blood draw: Looking through distraction cards is effective in pain relief of children during blood draw. International Journal of Nursing Practice, 18(2). Retrivied from http://onlinelibrary.wiley.com/doi/10.1111/j.1440172X.2012.02016.X/

Croww, J, et al (2013). Best Practices For Pain Reduction Associated With Venipuncture In Children. $\begin{array}{lllll}\text { Diunduh } & \text { tanggal } & 14 & \text { November }\end{array}$ http://www.uaa.alaska.edu/schoolofnursing/upload/Venipuncture-Pain.

Kyle, Terri. 2008. Essentials of Pediatric Nursing. Philadelphia : Wolters Kluwer

Lander JA, Weltman BJ, So SS. EMLA And Amethocaine For Reduction Of Children's Pain Associated With Needle Insertion. Diunduh tanggal 16 November 2014 dari http://www.rigshospitalet.dk/NR/rdonlyres/24B17E18-6019-4262-958D-

E9C22D20D0BB/0/CochranereviewEmlaandamethocaine.pdf

Latta \& Buoy (2012). Use Of Cold And Vibration During IV Insertion In Pediatric Patients. Diunduh tanggal 30 September 2014. www.advocatehealth.com/.

Lestari K. B (2013). Dampak Dekapan Keluarga Dan Pemberian Posisi Duduk Terhadap Distress Anak Saat Dilakukan Pemasangan Infus. http:// lib.ui.ac.id/file?file=digital/. Thesis (tidak dipublikasikan)

Liu, M., Lin, K., Chou, Y., \& Lee, T. (2010). Using Non-Nutritive Sucking And Oral Glucose Solution With Neonates To Relieve Pain: A Randomized Controlled Trial. Diunduh tanggal 14 November 2014 dari http://yadda.icm.edu.pl/yadda/element/bwmeta1.element.elsevier-d5880076-58b7$33 \mathrm{~b} 8$-ac5e-c77f2cb9bf03.

Mariyam\&Widodo (2012). Pengaruh Guided Imagery Terhadap Tingkat Nyeri Anak Usia 7-13 Tahun Saat Dilakukan Pemasangan Infuse Di RSUD Kota Semarang. Diunduh tanggal 15 Oktober 2014 dari http://jurnal.unimus.ac.id .

Na Ahn et all (2013). The Effects Of EMLA Cream On Pain Responses Of Preschoolers. Diunduh tanggal 10 Oktober 2014. www.scirp.org/journal/PaperDownload.aspx?paperID=40489.

NANDA (2012). Nursing Diagnoses Definition And Classification 2012-2014. Iowa: Wiley Blackwell 
Price \& Gwin (2008), Pediatric Nursing: An Introductory Text (11th edition). St Louis Missauri : Elsevevier

Sabeti, et al (2013). Which Is Better For Pain Reduction Before Venipuncture: Glucose, Lidocaine Or Expressed Breast Milk?. HK Journal Paediatr, 18:19-23. November 10, 2014.

Spark, Setlik \&Luhman (2007). Parental Holding and Positioning To Decrease IV Distress In Young Children: A Randomized Controlled Trial. Journal of Pediatric Nursing, 2(26), 440-447.

Sulistyani, Endah. 2009. Pengaruh Pemberian Kompres Es Batu Terhadap Penurunan Tingkat Nyeri Pada Anak Pra Sekolah Ynag Dilakukan Prosedur Pemasangan Infus Di RSUPN Dr Cipto $\begin{array}{lllll}\text { Mangunkusumo Jakarta. } & \text { Diunduh } & 15 & \text { Oktober } & 2014 .\end{array}$ http://eprints.lib.ui.ac.id/3959/8/124775\%2DTESIS0649\%20End\%20N09p\%2DPengaruh\%20P emberian\%2DPendahuluan.pdf. 